\title{
Revitalization of urban areas on the basis of industrial parks
}

\author{
Vladimir Filatov ${ }^{1, *}$, Grigory Yazev $^{1}$, Oksana Sagina ${ }^{1}$ \\ ${ }^{1}$ Moscow state University of technology and management. K. G. Razumovsky, 109004, Moscow, \\ Russia
}

\begin{abstract}
The issues of revitalization of urban areas on the basis of industrial parks at the present stage are considered in this paper. The development of a new service industry of territorial development industrial parks - has started in Russia less than 10 years ago and gradually acquires a systemic character. The issues of revitalization of urban areas are extremely relevant for many Russian cities. In the conditions of the necessity to search for new drivers for the economic growth of cities, to improve the quality of the urban environment, to increase the efficiency of the use of urban areas, an important task of finding and elaborating of innovation models for the development of industrial zones arises. A rich experience of reforming such areas has been accumulated in the world practice.
\end{abstract}

\section{Introduction}

The issues of revitalization of industrial territories in the cities of Russia are undoubtedly relevant. Each industrial city is unique and inimitable in its own way, but the town-planning policy of the state brings to these cities common features materialized in the appearance and architectural and planning content. The creation of separate complexes of ready-made modular premises has long been practiced in industrial parks of the world [1].

During conservation of industrial facilities and in the process of revitalization of production areas, all the basic architectural principles must be sustained. As a result, objects acquire historical value and become objects of the architectural heritage. It is possible that some unique production, capable of acting as an interesting object of industrial tourism, can become a symbol of the city or a part of its image.

\section{Materials and methods}

Typical structure of the main forms of organization of industrial parks is presented as a ratio of two parameters: the type of ownership of an industrial park - public or private, and the placement - an undeveloped land or industrial territory. Thus, possible combinations of parameters form four main types of industrial parks: a private industrial park of

\footnotetext{
*Corresponding author: filatov_vl@mail.ru
} 
"Greenfield" type, a private industrial park of "Brownfield" type, a state industrial park of "Greenfield" type, and a state industrial park of "Brownfield" type (Figure 1).

All types of industrial parks, regardless of ownership and location, must meet two key criteria: compliance with existing standards; functioning of a unified system of park maintenance and provision of services to residents under the management of a specialized company during the entire project implementation period. Projects that do not meet one of the criteria are referred to as industrial investment sites [2].

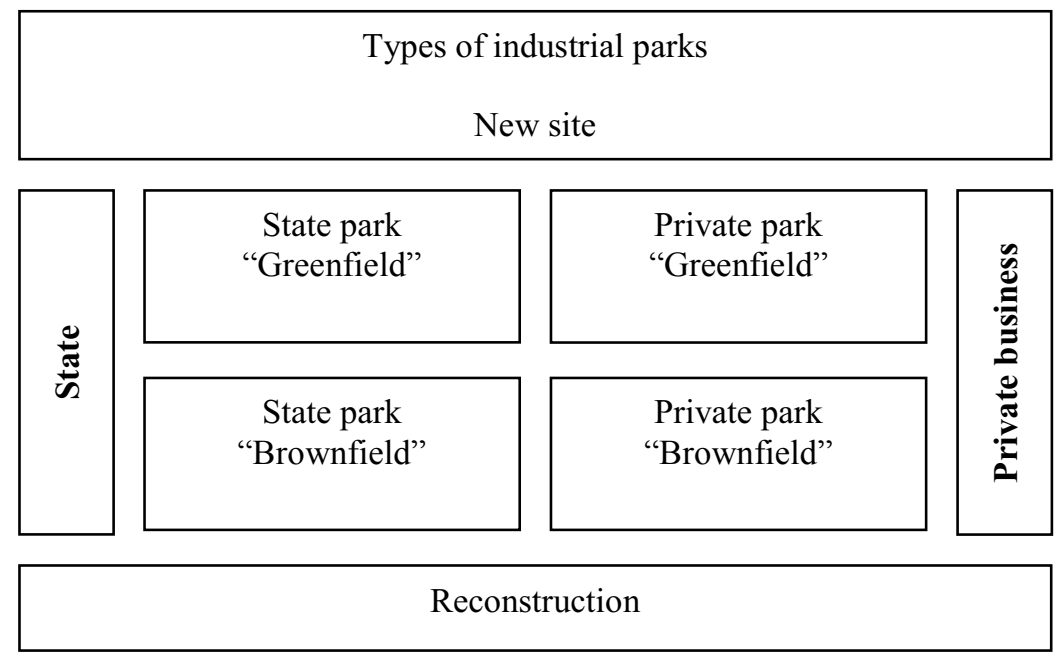

Fig. 1. Types of industrial parks.

At the present time, about 300 park-type formations are functioning in Russia. Their specificity is diverse: from universal, on the industrial sites of which there are residents of various sectors of the national economy (about 40\%), to specialized in the single industry machine industry $(16 \%)$, food industry $(8 \%)$, construction and construction materials $(5 \%)$, chemical industry (4\%) and other industries (metallurgy, oil and gas, pharmaceuticals and medical technologies), each of which has a percentage of $1-2 \%$ in the total structure of industrial parks [3]. Today, eco-industrial parks in Russia are developing on the initiative from below. Private business saw in them the sphere for investment of capital, regional authorities - a means to attract foreign investment. However, according to the Association of Industrial Parks of Russia, only 41 of them actually work and there is none that could fully comply with the standard of the industrial park in the Western opinion [4].

\section{Results}

At the present time, there is an urgent need to develop economic instruments to accelerate the reorganization of production areas with the help of the Moscow Administration and leading institutions. In addition, it is required to strengthen the city center of PPP (Publicprivate partnership) which is engaged in attraction of private investments and definition of express business projects on proposals for the rehabilitation of production areas.

In Moscow and other big cities, such as St. Petersburg and Vladivostok, this problem cannot be solved only by expansion of the network until the problem of location of city functions is not resolved. It is necessary to remove them from the center and redistribute them on a wider area. Innovative growth points are created on the new location in consequence of the mechanical transfer [5]. Typological classification of industrial parks is presented in Table 1. 
The objects of removal in the field of education were, first of all, technical universities. The distance was measured by the traveling time to the city center: one hour for technical and 30 minutes for humanities universities. At the same time, the range of removal of industrial enterprises was about $70-100 \mathrm{~km}$. However, in the removal of functions, the problem of desertification of the city arises. In this case, a plan of action must be foreseen in advance [6]. Polycentrism is necessary for Moscow: subcentres will continue to appear (Table 2).

According to analysts of the company CIAN, $45 \%$ of purchases were to sales in projects located on the site of the reconstructed industrial and communal areas of Moscow in 2013, in $2017-68 \%$. The share of such transactions in the total volume in the primary market will continue to grow in 2018. By the end of the year, the construction of 1.2 million square meters of housing is planned at the place of industrial zones. As noted in the message of CIAN, industrial zones have turned into the main points of growth of the city in the last few years [7].

The largest projects of the year 2018, implemented as a part of the revitalization of industrial areas of Moscow, will be residential complexes at the place of the First Automobile Repair Plant on Volnaya Street (Eastern Administrative District), the southern part of the ZIL (Southern AD), and the auto plant on Beregovaya Street in Fili (Western AD).

In Moscow, the "Golden Island" project is underway to revitalize the city's territory of the island in front of the Kremlin from the Bolshoy Moskvoretsky Bridge to the monument to Peter the Great on the Spit of the island. For the first time, conditions are created for the comprehensive development of the historic center territory of more than 40 hectares [8].

Buildings of the factory "Red October" on the western end of the island are the monuments of industrial architecture, which is planned to be reconstructed after their removal. Considering the height of the premises and the architecture of the buildings, it is proposed to place here various public functions and individual "lofts" - the places of residence and work of representatives of creative professions: artists, sculptors, designers, and architects.

On the place of demolished factory facilities that do not represent architectural value, it is planned to build an elite residential complex. Hotel, cafes and restaurants will be on the western part of the Spit of the Island in a place surrounded by water on three sides and remote from the city highways.

This territory, by virtue of its geographical location, is a very attractive recreational and walking area. All embankments on this site are turned into a greened walking area designed for free visits by Moscow residents and guests of the capital. The western part of the Spit will be connected by pedestrian bridges to the site of the monument to Peter the Great and the Park of Arts.

The problem of parking is successfully solved in this place. Two-storey underground parking with an area of about 50 thousand square meters will be located under the bottom of the hydraulic structure of the Vodootvodny Canal between the monument to Peter the Great and the Small Stone Bridge. Underground parking space will be connected with the underground part of the complex "Megapolis Center" on the Spit of the Island.

Table 1. Typological classification of industrial parks*.

\begin{tabular}{|c|c|c|c|c|c|c|}
\hline \multirow{3}{*}{$\begin{array}{c}\text { Typ } \\
\text { e }\end{array}$} & \multirow{3}{*}{$\begin{array}{l}\text { Concept of } \\
\text { the park }\end{array}$} & \multirow{3}{*}{$\begin{array}{c}\text { Project } \\
\text { participant } \\
\text { s and } \\
\text { clients }\end{array}$} & \multirow{3}{*}{$\begin{array}{c}\text { Sources of } \\
\text { project } \\
\text { financing: }\end{array}$} & \multicolumn{3}{|c|}{ Investment costs and project revenues } \\
\hline & & & & \multirow[t]{2}{*}{ Expenses } & \multicolumn{2}{|c|}{ Revenues } \\
\hline & & & & & $\begin{array}{c}\text { from } \\
\text { developmen } \\
t\end{array}$ & $\begin{array}{c}\text { from } \\
\text { operation }\end{array}$ \\
\hline
\end{tabular}




\begin{tabular}{|c|c|c|c|c|c|c|}
\hline 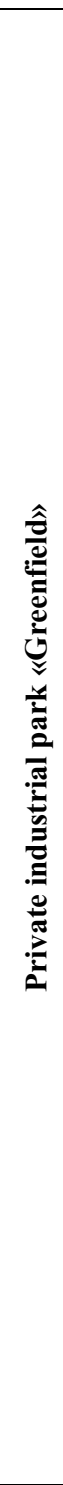 & $\begin{array}{l}1 . \\
\text { Creation of } \\
\text { a site for } \\
\text { the location } \\
\text { and } \\
\text { operation } \\
\text { of } \\
\text { production } \\
\text { capacities } \\
\text { of the } \\
\text { residents of } \\
\text { the park, } \\
\text { followed } \\
\text { by the sale } \\
\text { or lease of } \\
\text { relevant } \\
\text { sites. The } \\
\text { site } \\
\text { include: } \\
\text { prepared } \\
\text { land plots, } \\
\text { infrastructu } \\
\text { re, } \\
\text { auxiliary } \\
\text { buildings } \\
\text { and public } \\
\text { facilities; } \\
\quad 2 \text {. } \\
\text { Providing a } \\
\text { wide range } \\
\text { of services } \\
\text { and } \\
\text { outsourcing } \\
\text { to the } \\
\text { residents } \\
\text { by the } \\
\text { manageme } \\
\text { nt company } \\
\text { and } \\
\text { attracted } \\
\text { partners. }\end{array}$ & $\begin{array}{l}\text { Private } \\
\text { owner of } \\
\text { industrial } \\
\text { park assets; } \\
\text { management } \\
\text { company; } \\
\text { developmen } \\
\text { t company; } \\
\text { service } \\
\text { companies } \\
\text { that provide } \\
\text { services to } \\
\text { the residents } \\
\text { of the park; } \\
\text { companies } \\
\text { that provide } \\
\text { resources; } \\
\text { resident } \\
\text { companies. }\end{array}$ & $\begin{array}{l}\text { Long-term } \\
\text { investments } \\
\text { of banks and } \\
\text { credit } \\
\text { organization } \\
\text {; } \\
\text { investments } \\
\text { of the large } \\
\text { ("anchored") } \\
\text { residents of } \\
\text { the project; } \\
\text { own means } \\
\text { of the project } \\
\text { initiator. }\end{array}$ & $\begin{array}{l}\text { Purchase of } \\
\text { land; land } \\
\text { survey } \\
\text { works; } \\
\text { development } \\
\text { of the } \\
\text { concept of } \\
\text { the industrial } \\
\text { park; } \\
\text { development } \\
\text { and state } \\
\text { expertise of } \\
\text { design and } \\
\text { estimate } \\
\text { documentati } \\
\text { on; } \\
\text { engineering } \\
\text { survey; } \\
\text { preparation } \\
\text { of site; } \\
\text { building of } \\
\text { networks; } \\
\text { construction } \\
\text { of buildings } \\
\text { and public } \\
\text { facilities. }\end{array}$ & $\begin{array}{l}\text { Sale of land; } \\
\text { construction } \\
\text { for the needs } \\
\text { of the } \\
\text { customer; } \\
\text { long term } \\
\text { rental; } \\
\text { payback } \\
\text { period from } \\
7 \text { to } 12 \\
\text { years; } \\
\text { project } \\
\text { implementati } \\
\text { on period } \\
\text { from } 7 \text { years. }\end{array}$ & $\begin{array}{l}\text { Build to suite; } \\
\text { electric } \\
\text { power, heat, } \\
\text { and water } \\
\text { supply; } \\
\text { sewage } \\
\text { treatment and } \\
\text { water } \\
\text { disposal; } \\
\text { processing of } \\
\text { chemical and } \\
\text { industrial } \\
\text { waste; } \\
\text { management } \\
\text { company } \\
\text { services. }\end{array}$ \\
\hline
\end{tabular}




\begin{tabular}{|c|c|c|c|c|c|c|}
\hline 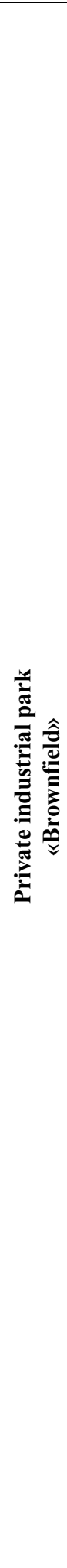 & $\begin{array}{l}\text { 1. } \\
\text { Creation of } \\
\text { a site for } \\
\text { the location } \\
\text { and } \\
\text { operation } \\
\text { of } \\
\text { production } \\
\text { capacities } \\
\text { of the } \\
\text { residents of } \\
\text { the park on } \\
\text { the basis of } \\
\text { the existing } \\
\text { industrial } \\
\text { territory, } \\
\text { followed } \\
\text { by the sale } \\
\text { or lease of } \\
\text { the relevant } \\
\text { plots, } \\
\text { buildings, } \\
\text { structures } \\
\text { and their } \\
\text { parts. The } \\
\text { site } \\
\text { includes: } \\
\text { buildings } \\
\text { and } \\
\text { workshops } \\
\text { for location } \\
\text { of } \\
\text { production } \\
\text { facilities, } \\
\text { built and } \\
\text { reconstruct } \\
\text { ed } \\
\text { infrastructu } \\
\text { re, } \\
\text { auxiliary } \\
\text { buildings } \\
\text { and public } \\
\text { facilities; } \\
\text { Pr. } \\
\text { Providing a } \\
\text { wide range } \\
\text { of services } \\
\text { and } \\
\text { outsourcing } \\
\text { to the } \\
\text { residents } \\
\text { by the } \\
\text { manageme } \\
\text { nt company } \\
\text { and attracted } \\
\text { partners. }\end{array}$ & $\begin{array}{l}\text { Private } \\
\text { owner of } \\
\text { industrial } \\
\text { park assets; } \\
\text { management } \\
\text { company; } \\
\text { developmen } \\
\text { t company; } \\
\text { service } \\
\text { companies } \\
\text { that provide } \\
\text { services to } \\
\text { the residents } \\
\text { of the park; } \\
\text { companies } \\
\text { that provide } \\
\text { resources; } \\
\text { resident } \\
\text { companies. }\end{array}$ & $\begin{array}{l}\text { Long-term } \\
\text { investments } \\
\text { of banks and } \\
\text { credit } \\
\text { organization } \\
\text { s; } \\
\text { investments } \\
\text { of the large } \\
\text { ("anchored") } \\
\text { residents of } \\
\text { the project; } \\
\text { own means } \\
\text { of the project } \\
\text { initiator. }\end{array}$ & $\begin{array}{l}\text { Purchase of } \\
\text { land; land } \\
\text { survey } \\
\text { works; } \\
\text { development } \\
\text { of the } \\
\text { concept of } \\
\text { the industrial } \\
\text { park; } \\
\text { development } \\
\text { and state } \\
\text { expertise of } \\
\text { design and } \\
\text { estimate } \\
\text { documentati } \\
\text { on; } \\
\text { engineering } \\
\text { survey; } \\
\text { clearing and } \\
\text { preparation } \\
\text { of the site; } \\
\text { construction } \\
\text { and } \\
\text { reconstructio } \\
\text { n n of } \\
\text { networks; } \\
\text { construction } \\
\text { of buildings } \\
\text { and public } \\
\text { facilities; } \\
\text { construction } \\
\text { of industrial } \\
\text { buildings. }\end{array}$ & $\begin{array}{l}\text { Sale of land; } \\
\text { construction } \\
\text { for the needs } \\
\text { of the } \\
\text { customer; } \\
\text { long term } \\
\text { rental; } \\
\text { payback } \\
\text { period from } \\
7 \text { to } 12 \\
\text { years; } \\
\text { project } \\
\text { implementati } \\
\text { on period } \\
\text { from } 7 \text { years. }\end{array}$ & $\begin{array}{l}\text { Build to suite; } \\
\text { electric } \\
\text { power, heat, } \\
\text { and water } \\
\text { supply; } \\
\text { sewage } \\
\text { treatment and } \\
\text { water } \\
\text { disposal; } \\
\text { processing of } \\
\text { chemical and } \\
\text { industrial } \\
\text { waste; } \\
\text { services of the } \\
\text { management } \\
\text { company. }\end{array}$ \\
\hline
\end{tabular}




\begin{tabular}{|c|c|c|c|c|c|c|}
\hline 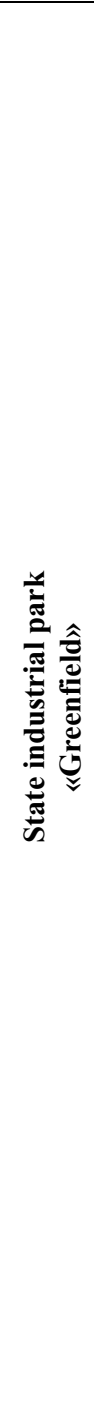 & $\begin{array}{l}\text { 1. } \\
\text { Creation of } \\
\text { a site for } \\
\text { the location } \\
\text { and } \\
\text { operation } \\
\text { of } \\
\text { production } \\
\text { capacities } \\
\text { of the } \\
\text { residents of } \\
\text { the park, } \\
\text { followed } \\
\text { by the lease } \\
\text { of relevant } \\
\text { sites. The } \\
\text { site } \\
\text { includes: } \\
\text { prepared } \\
\text { land plots, } \\
\text { infrastructu } \\
\text { re, } \\
\text { auxiliary } \\
\text { buildings } \\
\text { and public } \\
\text { facilities; } \\
2 . \\
\text { Providing a } \\
\text { wide range } \\
\text { of services } \\
\text { and } \\
\text { outsourcing } \\
\text { to the } \\
\text { residents } \\
\text { by the } \\
\text { manageme } \\
\text { nt company } \\
\text { and attracted } \\
\text { partners. }\end{array}$ & $\begin{array}{l}\text { Administrati } \\
\text { on of the } \\
\text { federal } \\
\text { subject of } \\
\text { the Russian } \\
\text { Federation, } \\
\text { municipality } \\
\text {; State } \\
\text { owner of } \\
\text { industrial } \\
\text { park assets } \\
\text { (or } \\
\text { developmen } \\
\mathrm{t} \\
\text { corporation) } \\
; \\
\text { management } \\
\text { company (or } \\
\text { developmen } \\
\mathrm{t} \\
\text { corporation) } \\
\text {; } \\
\text { developmen } \\
\mathrm{t} \text { company } \\
\text { (or } \\
\text { developmen } \\
\mathrm{t} \\
\text { corporation) } \\
; \quad \text { service } \\
\text { companies } \\
\text { that provide } \\
\text { services to } \\
\text { residents of } \\
\text { the park; } \\
\text { companies } \\
\text { that provide } \\
\text { resources; } \\
\text { resident } \\
\text { companies. }\end{array}$ & $\begin{array}{l}\text { Federal, } \\
\text { regional and } \\
\text { local } \\
\text { budgets; } \\
\text { long-term } \\
\text { investments } \\
\text { of banks and } \\
\text { credit } \\
\text { organization } \\
\text { s; private } \\
\text { investments } \\
\text { (extrabudget } \\
\text { ary funds). }\end{array}$ & $\begin{array}{l}\text { Land survey } \\
\text { works; } \\
\text { development } \\
\text { of the } \\
\text { concept of } \\
\text { the industrial } \\
\text { park; } \\
\text { development } \\
\text { and state } \\
\text { expertise of } \\
\text { design and } \\
\text { estimate } \\
\text { documentati } \\
\text { on; } \\
\text { engineering } \\
\text { survey; } \\
\text { preparation } \\
\text { of site; } \\
\text { building of } \\
\text { networks; } \\
\text { construction } \\
\text { of buildings } \\
\text { and public } \\
\text { facilities; } \\
\text { expenses of } \\
\text { the me } \\
\text { management } \\
\text { company. }\end{array}$ & $\begin{array}{l}\text { Profit under } \\
\text { the trust } \\
\text { management } \\
\text { agreement } \\
\text { (if the } \\
\text { management } \\
\text { company is a } \\
\text { private } \\
\text { company); } \\
\text { tax revenues; } \\
\text { sale of land; } \\
\text { long term } \\
\text { rental; } \\
\text { payback } \\
\text { period from } \\
7 \text { to } 15 \\
\text { years; } \\
\text { project } \\
\text { implementati } \\
\text { on period } \\
\text { from } 7 \text { years. }\end{array}$ & $\begin{array}{l}\text { Build to suite } \\
\text { (at the stage } \\
\text { of project } \\
\text { implementatio } \\
\text { n); electric } \\
\text { power, heat, } \\
\text { and water } \\
\text { supply; } \\
\text { sewage } \\
\text { treatment and } \\
\text { water } \\
\text { disposal; } \\
\text { processing of } \\
\text { chemical and } \\
\text { industrial } \\
\text { waste; } \\
\text { services of the } \\
\text { management } \\
\text { company; tax } \\
\text { revenues from } \\
\text { resident } \\
\text { companies. }\end{array}$ \\
\hline
\end{tabular}




\begin{tabular}{|c|c|c|c|c|c|c|}
\hline 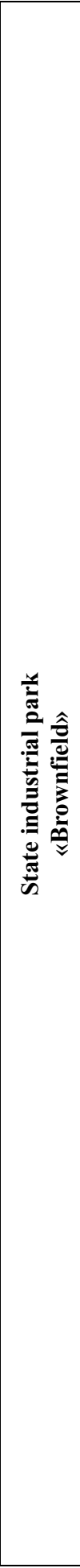 & $\begin{array}{l}\text { 1. Creation } \\
\text { of a site for } \\
\text { the location } \\
\text { and } \\
\text { operation } \\
\text { of } \\
\text { production } \\
\text { capacities } \\
\text { of the } \\
\text { residents of } \\
\text { the park on } \\
\text { the basis of } \\
\text { the existing } \\
\text { industrial } \\
\text { territory, } \\
\text { followed } \\
\text { by the lease } \\
\text { of relevant } \\
\text { plots, } \\
\text { buildings, } \\
\text { structures } \\
\text { and their } \\
\text { parts. The } \\
\text { site } \\
\text { includes: } \\
\text { buildings } \\
\text { and } \\
\text { workshops } \\
\text { for locating } \\
\text { production } \\
\text { facilities, } \\
\text { built and } \\
\text { reconstruct } \\
\text { ed } \\
\text { infrastructu } \\
\text { re, } \\
\text { auxiliary } \\
\text { buildings } \\
\text { and public } \\
\text { facilities. } \\
2 . \\
\text { Providing a } \\
\text { wide range } \\
\text { of services } \\
\text { and } \\
\text { outsourcing } \\
\text { to the } \\
\text { residents } \\
\text { by the } \\
\text { manageme } \\
\text { nt company } \\
\text { and attracted } \\
\text { partners. }\end{array}$ & $\begin{array}{l}\text { Administrati } \\
\text { on of the } \\
\text { federal } \\
\text { subject of } \\
\text { the Russian } \\
\text { Federation, } \\
\text { municipality } \\
\text {; State } \\
\text { owner of } \\
\text { industrial } \\
\text { park assets } \\
\text { (or } \\
\text { developmen } \\
t \\
\text { corporation) } \\
; \\
\text { management } \\
\text { company (or } \\
\text { developmen } \\
t \\
\text { corporation) } \\
; \\
\text { developmen } \\
t \text { company } \\
\text { (or } \\
\text { developmen } \\
t \\
\text { corporation) } \\
\text {; service } \\
\text { companies } \\
\text { that provide } \\
\text { services to } \\
\text { residents of } \\
\text { the park; } \\
\text { companies } \\
\text { that provide } \\
\text { resources; } \\
\text { resident } \\
\text { companies. }\end{array}$ & $\begin{array}{l}\text { Federal, } \\
\text { regional and } \\
\text { local } \\
\text { budgets; } \\
\text { regional } \\
\text { development } \\
\text { budget; } \\
\text { subsidies of } \\
\text { the federal } \\
\text { budget under } \\
\text { the program } \\
\text { of state } \\
\text { support of } \\
\text { small and } \\
\text { medium } \\
\text { business; } \\
\text { private } \\
\text { investments } \\
\text { (extrabudget } \\
\text { ary funds). }\end{array}$ & $\begin{array}{l}\text { Land survey } \\
\text { works; } \\
\text { development } \\
\text { of the } \\
\text { concept of } \\
\text { an industrial } \\
\text { park; } \\
\text { development } \\
\text { and state } \\
\text { expertise of } \\
\text { design and } \\
\text { estimate } \\
\text { documentati } \\
\text { on; } \\
\text { engineering } \\
\text { survey; } \\
\text { preparation } \\
\text { of site; } \\
\text { building of } \\
\text { networks; } \\
\text { construction } \\
\text { of buildings } \\
\text { and public } \\
\text { facilities; } \\
\text { expenses of } \\
\text { the } \\
\text { management } \\
\text { company }\end{array}$ & $\begin{array}{l}\text { Profit under } \\
\text { the trust } \\
\text { management } \\
\text { agreement } \\
\text { (if the } \\
\text { management } \\
\text { company is a } \\
\text { private } \\
\text { company); } \\
\text { tax revenues; } \\
\text { sale of land, } \\
\text { buildings } \\
\text { and structures; } \\
\text { long term } \\
\text { rental; } \\
\text { payback } \\
\text { period from } \\
7 \text { to } 15 \\
\text { years; } \\
\text { project } \\
\text { implementati } \\
\text { on period } \\
\text { from } 7 \text { years. }\end{array}$ & $\begin{array}{l}\text { Build to suite } \\
\text { (at the stage } \\
\text { of project } \\
\text { implementatio } \\
\text { n); electric } \\
\text { power, heat, } \\
\text { and water } \\
\text { supply; } \\
\text { sewage } \\
\text { treatment and } \\
\text { water } \\
\text { disposal; } \\
\text { processing of } \\
\text { chemical and } \\
\text { industrial } \\
\text { waste; } \\
\text { services of the } \\
\text { management } \\
\text { company; tax } \\
\text { revenues from } \\
\text { resident } \\
\text { companies. }\end{array}$ \\
\hline
\end{tabular}

* Prepared on the basis of the Methodological recommendations for the creation of an industrial park, NP "Association of Industrial Parks", 2014. 
Table 2. Realized projects of revitalization of urban areas on the basis of creation of industrial parks*.

\begin{tabular}{|c|c|c|c|c|c|c|c|c|}
\hline \multicolumn{2}{|c|}{ Name } & $\begin{array}{c}\text { Techno } \\
\text { polis } \\
\text { "Mosco } \\
\text { w" }\end{array}$ & $\begin{array}{c}\text { Techno } \\
\text { park } \\
\text { "Slava" }\end{array}$ & $\begin{array}{c}\text { Techno } \\
\text { park } \\
\text { "Strogi } \\
\text { no" }\end{array}$ & $\begin{array}{c}\text { Technopa } \\
\text { rk } \\
\text { "Mosgor } \\
\text { mash" }\end{array}$ & $\begin{array}{c}\text { Special } \\
\text { economi } \\
\text { c zone } \\
\text { "Zelenog } \\
\text { rad" }\end{array}$ & $\begin{array}{c}\text { Techno } \\
\text { park } \\
\text { «STMP- } \\
\text { Zelenog } \\
\text { rad» }\end{array}$ & $\begin{array}{c}\text { Busin } \\
\text { ess } \\
\text { incub } \\
\text { ator } \\
\text { KP } \\
\text { "KRZ } \\
"\end{array}$ \\
\hline \multicolumn{2}{|c|}{ Location } & \multicolumn{2}{|c|}{$\begin{array}{l}\text { South-East of } \\
\text { Moscow }\end{array}$} & $\begin{array}{l}\text { South of } \\
\text { Moscow }\end{array}$ & $\begin{array}{c}\text { North- } \\
\text { West of } \\
\text { Moscow }\end{array}$ & \multicolumn{3}{|c|}{ North of Moscow } \\
\hline & Area, ha & 30,5 & 2.8 & 6,43 & 2.3 & 145,8 & 12 & 0,2 \\
\hline \multicolumn{2}{|c|}{$\begin{array}{c}\text { Effective area } \\
\text { (sq.m.) }\end{array}$} & $\begin{array}{c}2014- \\
366819\end{array}$ & $\begin{array}{l}2014- \\
30953\end{array}$ & $\begin{array}{l}2014- \\
33534\end{array}$ & $\begin{array}{c}2014-17 \\
386 \\
2017- \\
32895\end{array}$ & & $\begin{array}{l}2014- \\
25112\end{array}$ & $\begin{array}{c}2014- \\
9100\end{array}$ \\
\hline \multirow{8}{*}{ 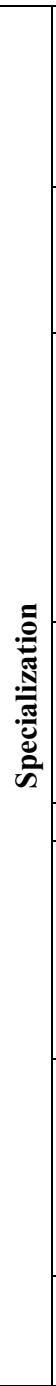 } & $\begin{array}{l}\text { Modern / } \\
\text { new } \\
\text { materials } \\
\text { and } \\
\text { surfaces }\end{array}$ & $\mathrm{x}$ & & $\mathrm{x}$ & & & & \\
\hline & $\begin{array}{c}\text { Nanotechn } \\
\text { ologies and } \\
\text { nanomateri } \\
\text { als }\end{array}$ & & $\mathrm{x}$ & & & & & $\mathrm{x}$ \\
\hline & $\begin{array}{c}\text { Medical } \\
\text { equipment } \\
\text { and } \\
\text { materials, } \\
\text { pharmaceu } \\
\text { ticals and } \\
\text { biotechnolo } \\
\text { gy }\end{array}$ & $\mathrm{x}$ & $\mathrm{x}$ & & $\mathrm{x}$ & $\mathrm{x}$ & & \\
\hline & $\begin{array}{l}\text { Microelectr } \\
\text { onics, } \\
\text { electronic } \\
\text { devices and } \\
\text { equipment }\end{array}$ & $\mathrm{x}$ & & & & $\mathrm{x}$ & $\mathrm{x}$ & $x$ \\
\hline & Robotics & & $\mathrm{x}$ & & & & & $\mathrm{x}$ \\
\hline & $\begin{array}{c}\text { Informatio } \\
\text { n and } \\
\text { communica } \\
\text { tion } \\
\text { technologie } \\
\text { s }\end{array}$ & $\mathrm{x}$ & $\mathrm{x}$ & $\mathrm{x}$ & $\mathrm{x}$ & $\mathrm{x}$ & $\mathrm{x}$ & $\mathrm{x}$ \\
\hline & $\begin{array}{c}\text { Energy } \\
\text { efficiency } \\
\text { and energy } \\
\text { saving } \\
\text { technologie } \\
\text { s }\end{array}$ & & $\mathrm{x}$ & $\mathrm{x}$ & $\mathrm{x}$ & $\mathrm{x}$ & $\mathrm{x}$ & $\mathrm{x}$ \\
\hline & \begin{tabular}{|c|}
$\begin{array}{c}\text { Alternative } \\
\text { forms of } \\
\text { energy }\end{array}$ \\
\end{tabular} & & & $\mathrm{x}$ & & & & \\
\hline
\end{tabular}




\begin{tabular}{|c|c|c|c|c|c|c|c|}
\hline \multicolumn{4}{|c|}{ Utility networks } \\
\hline $\begin{array}{c}\text { Water supply, } \\
\mathbf{m}^{\mathbf{3} / \mathbf{d a y}}\end{array}$ & 1200 & 1440 & 22 & 90 & 2400 & 72,7 & 8,3 \\
\hline $\begin{array}{c}\text { Electric power } \\
\text { supply, } \\
\text { megawatt }\end{array}$ & 60 & 6 & 4,2 & 1,2 & 60 & 2,9 & 1,2 \\
\hline $\begin{array}{c}\text { Heat supply, } \\
\text { gcal/hour }\end{array}$ & 163 & 5,7 & - & 2,9 & 180,1 & 180,3 & 0,3 \\
\hline $\begin{array}{c}\text { Water drainage } \\
\text { system, } \mathbf{~ m}^{\mathbf{3}} \text { / day }\end{array}$ & 1200 & 1440 & - & 80,5 & 1800 & 72,7 & 30 \\
\hline
\end{tabular}

* Prepared on the basis of the Department of Science, Industrial Policy and Entrepreneurship of Moscow.

The project of Sir Norman Foster on the revitalization of the territories of New Holland Island in St. Petersburg is a triangular island on its own supports with a variety of cultural institutions located on the area of 7.6 hectares. The project includes a theater, conference rooms, galleries, a hotel, shops, apartments and restaurants with a moving arena in the center [9].

Following the contours of the existing port pool, the open air arena will be surrounded by the theater, boutiques and restaurants overlooking the water. It is mainly intended for performances in the open air. If necessary, it can be filled with water (for regattas), and also filled with ice for use as a rink. The project also provides the infrastructure for connection with the city. New bridges and roads will be built.

One of the successful objects of reconstruction of an industrial facility, implemented by Russian architects, is a museum of water on the territory of Vodokanal in St. Petersburg. Reconstruction of the water tower building is the first experience in St. Petersburg of revitalizing old industrial buildings that have lost their former purpose. This project is an experiment in mixing styles of the XIX and XXI centuries. The main task was to restore, clean from latest "layers", and adapt to new functions of the inner spaces of the tower, and preservation of the entirety of interiors - beautiful halls with arched ceilings.

The red-brick octahedron of the water tower, designed by the architects Merz and Shubersky in 1860-1863, is connected with water only functionally: monolithic volume denies any fluidity. The architects of the "Intercolumnium" studio, who were reconstructing the tower, managed to solve not only the content issues - the placement of "The Universe of Water" Museum Complex in the Tower, but also figurative. Requirements for the preservation of historic interiors of the Tower determined the removal of the elevator and stairs in the separate annex. It was this annex who became the main accent of reconstruction. One can read the image of water in its forms and material. Together with the tower, the territory around the museum was successfully transformed. The garden is laid out, the fountain is arranged, and sculptures are put.

In early 2018, Japanese architectural bureau Nikken Sekkei announced a master plan implying the revitalization of urban areas and the modernization of urban infrastructure of Vladivostok. This master plan involves creating opportunities for the development of tourism and innovative industrial sectors. In particular, the proposal of the Japanese bureau suggests such strategic changes as the modernization of the central streets of the city and the coastal zone of Vladivostok, the creation of new industrial zones and business centers, and the development of public transport network. The innovative project involves the creation of tourist attractions, the modernization and arrangement of areas adjacent to the city's railway stations, as well as the introduction of an automatic traffic light control system based on data on the number of cars on the roads. 
As a part of the state program for the development of single industry towns, different industrial parks have been created and are being created. For example, such parks as the intermunicipal IP "Sheksna" in Cherepovets; IP specializing in woodworking in the city of Sokol (Vologda region); IP "Molot" in the city of Vyatskie Polyany (Kirov region); IP "Chistopol" (Republic of Tatarstan), the key activity of which has become the traditional for the region production of products for the precision instruments industry. The unit cost of construction of an industrial park, taking into account design, is shown in Figure 2. The diagram of the ratio of cost elements when creating a park with the area of 500 hectares is presented in Figure 3 [9].

In the geographical distribution of ecological industrial parks, the leading regions have long been defined. These are the Moscow, Leningrad, Kaluga, Ulyanovsk regions and the Republic of Tatarstan. It should be noted that the Moscow and Leningrad regions are more on the European way in the development of industrial parks - it is in these regions where the largest number of private industrial parks are concentrated. A number of industrial parks in Russia have a clear sectoral structure. These sites include industrial parks "Grabtsevo", "Kaluga-Yug", "Lafarge-Kaluga", and "A Plus Park Alabuga".

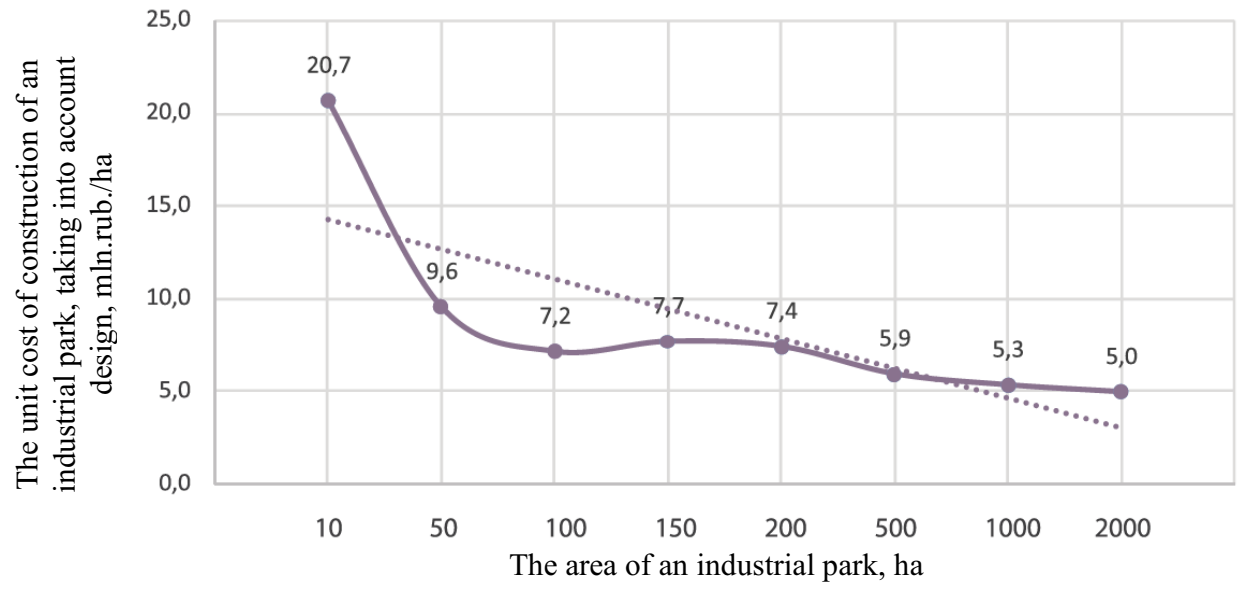

Fig. 2. The unit cost of construction of an industrial park, taking into account design.
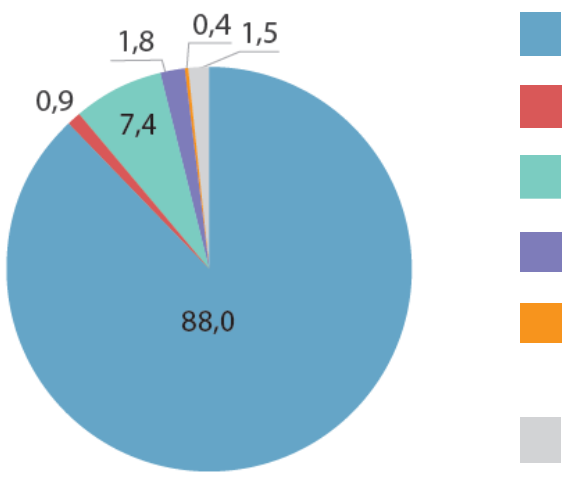

cost of construction of an industrial park, taking into account design cost of the concept

cost of a land plot

costs for the functioning of management company during 3 years costs for promotion of the site during 3 years

costs for obtaining initial permit documentation and transfer of land to the category of industry

Fig. 3. The ratio of cost elements when creating a park with the area of 500 ha.

The basis of urban policy should be provision of a comfortable environment for 
residents of the city: the place of employment and recreation. Only the construction of industrial parks, technoparks, technopolises, and business incubators can't solve the problem. The idea of polycentric city can be realized due to revitalization of depressed production territories:

- Synchronization of development programs, development of a specific program for the reorganization and development of production areas should be ensured. A comprehensive strategy for the removal and new deployment of city functions are needed, as well as a legislative system for its implementation.

- Formation of the city policy of "balanced development", the goal of which should be a harmonious formation of the environment for living of the inhabitants of the city: places of employment, recreation, living. New territories should attract young people, holders of innovative knowledge.

- Preservation of productions which are important for the city. For the harmonious development of the megalopolis, one can't take into account the opinion of each land user. Investors are not attracted to the development projects with a payback period of more than 5 years; commercialization of the leading scientific developments requires 10 years or more.

- The need to improve the energy efficiency of production. New construction is cheaper at the investment stage. Energy-efficient and environmentally friendly technologies should become mandatory. Ecological buildings are economically more profitable.

\section{Conclusion}

Even at the high rates of implementation of projects for revitalization of urban areas on the basis of industrial parks, import substitution will become an important factor only after 2-3 years, after the launch of at least a part of the planned projects. It is advisable to use legal schemes that implement the "win-win" principle, such as:

1) creation of specialized real estate closed end funds. (All process participants are located in a certain territory according to the calculated public interest of the city);

2) a scheme of investment partnerships. (Implemented through the draft law along with mutual investment funds; effective for territories with a large number of owners);

3) a scheme for concluding an agreement on the integrated implementation of planning projects. (Agreement of owners, who have rights to the land, on their plans for transformation, distribution of finances, time of performance and functional purpose of the facilities).

It's possible to separate out special economic regimes for industrial zones, innovation areas and industrial parks and, at the same time, continue to compensate for the costs of reprofiling and relocation, to give a bonus for the active work of economic entities. It is possible to impose sanctions on residents of industrial zones who do not lead innovation and industrial activities. Projects on the relocation of industrial zones should motivate and support economic entities.

Therefore, the analysis of the development and the social and economic importance of industrial parks in Russia showed that the projects for revitalization of urban areas on the basis of industrial parks have a great potential for positive impacts on the development of the territory on which the innovation project is implemented. These are an increase in the investment attractiveness of the territory for business, the formation of its industry specialization, stimulation of entrepreneurial activities, and improving the quality of life of the population.

\section{References}


1. P.G. Grabovy, A.K. Orlov, Procedia Engineering 153, 195-202 (2016)

2. V.S. Kankhva, Immovable property: economy, management 3, 17-19 (2009)

3. A.D. Ishkov, M.Yu. Mishlanova, K.P. Grabovyi, International Journal of Applied Engineering Research 11(3), 1676-1679 (2016)

4. P.I. Burak, I.A. Rozhdestvenskaya, I.M. Rukina, Osnovy ehkonomiki krupnogo goroda. Monografiya (Ekonomika, Moskva, 2009)

5. I.V. Polozhenceva, V.V. Filatov, Vestnik Universiteta 16, 117-122 (2012)

6. Zh.N. Dibrova, Teoreticheskie osnovy scenarnogo upravleniya vysshimi uchebnymi zavedeniyami v regione. Monografiya (Universitetskaya kniga, Kursk, 2016)

7. Importozameshchenie v kontekste razvitiya tekhnologicheskih ukladov, EHkonomika i predprinimatel'stvo 10-2(75-2), 459-464 (2016)

8. E.K. Chirkunova, E.E. Kireeva, A.D. Kornilova, J.S. Pschenichnikova, Procedia Engineering 153, 112-117 (2016)

9. P.G. Grabovyi, I.P. Avilova, A.V. Sharapova, Life Science Journal 11, 1097 (2014) 